\title{
移動床河川の弯曲部における二次流と 動的横断平衡河床について

\author{
ON SECONDARY FLOW AND DYNAMIC EQUILIBRIUM OF TRANSVERSE \\ BED PROFILE IN ALLUVIAL CURVED OPEN CHANNEL
}

\author{
池田 駿 介* \\ By Syunsuke Ikeda
}

\section{1. 序論}

自然の河川では平面形状が直線的となることはほとん どなく, 程度の多少はあるにせよ曲がりくねった蛇行形 状を示す。このような河川弯曲部における流れ, あるい は河床形状がどのような特性を示すかということは取水 設備, 水制等の河川構造物の設置, 掃流砂量, あるいは 最大洗掘深とも関係する舟運といったような実際的な諸 問題と相まって, 河川水理学上の重要な課題の一つであ る。

このような実際的な要請から 19 世紀から 20 世紀初 頭にかけては主に野外観測に基づいて河床形状に関する 研究が行われ, Fargue (1908), Ripley (1928) らはか れらの観測をまとめ経験式を提案している。

最近になって, ようやくこれらの現象について力学的 な観点から考察が加えられるようになってきた。

須賀 $(1965 ， 1966 ， 1969)$ は主流の速度分布を指数型 で表現し, 相当粗度を流砂量関数で表わし, さらに限界 掃流力関数を定義することによって河床上のすべての点 で限界掃流力になっている静的平衡河床を求めた。ま た, 河床に扔けるせん断力の分布を仮定し, 流砂量公式 を導入することによって動的平衡河床を求め, 実験との 比較を行った。彼の理論は河床のせん断力が弯曲部では 横断方向に均一でなく外岸側で増大することから流砂量 の不均一が生じ, そのために直線部と比べて外岸側が掘 れ, 内岸側で堆積が生ずるものとしている。また, 彼は 斜面上の掃流砂に働く力のつり合いを考慮することによ って静的および動的平衡河床を理論的に求めたが，その 際に半径方向の河床せん断力 $\tau_{r}$ (二次流々密接に関連 する) を決定するのに用いられている比例係数 $m$ と水 理量の関係が明白でなく, 今後の課題であることが述べ られている。
Yen, C.L. (1970) は動的平衡河床形を表わす式とし $\tau$,

$$
\frac{\partial \eta}{\partial s}=-K \frac{\bar{U}_{r \max }}{\sqrt{\frac{g d}{\frac{\rho_{s}}{\rho}-1}}}
$$

を得た。ここに $\eta$ は平均河床高からのずれ, $\bar{U}_{r \max }$ は $\mathrm{R}$ 地点における二次流の最大值, $K$ は未知量を含む比 例定数である。彼の理論では二次流と河床形状の関係が 得られたが，上式では $\rho_{s} / \rho$ が大きくなるほど，すなわ ち粒子の比重が大きいほど, 横断方向の河床勾配は大き くなることになり，実際の物理現象と矛盾する。しか し, 彼は $\bar{U}_{r \max }$ を測定し, 上式によって河床形状を求 め，それが測定された河床形状とよく一致することを示 した。

一方, 非定常問題については村本ら (1968) によって 研究が行われ, 流砂の連続式, 流砂量式, 河床高と流れ を関係づける式を連立させ，らせん流による流線のねじ れを考慮して方程式を数值的に解き, 初期の河床変動の 機構を取扱っている。

これらの実際的な 要請, あるいは研究の現況に 鑑み て, 本稿では実際的に最も重要である 動的平衡横断河 床, 最大洗掘深についてその力学的機構を明らかにし, 定量的な把握を行らことを目的とした。これらの目的を 達するために 2. 章では弯曲部の河床にある砂粒子に働 く力を考えることによって平衡河床形状を表わす式が導 かれ，それが河床における二次流の速度成分と密接な関 係にあることが示される。3.章においては任意の横断面 形を持つ弯曲開水路に㧍ける二次流の速度分布を表わす 式が導かれ，このようにして求められた二次流を表わす 式と 2. 章で得られた河床形状を表わす式を連立させて 解くことによって 4. 章では平衡河床形を解析的に求め る。

ここでは流れおよび河床の形状が流れ方向に変化しな くなった場合について取扱っているが，固定床の長方形 
断面を持つ弯曲部流れでは流入部から 130 度〜150 度流 下しないとこのような完全発達域に 達しないのに比べ て, 移動床の場合には流れと河床の相互依存によって固 定床の場合よりも早く完全発達域に達する。たとえば, 図一9, 11 では流入部から約 30 度程度でこの領域に達し ていることがわかるが，一般には河川の曲率半径と幅の 比,弯曲角等の関数であることが経験的に知られている。

\section{2. 砂粒子に働くカの評価, および平衡河床形 を表現する方程式の誘導}

理論の展開を行う前に, 弯曲部の流れにおける底の砂 粒子の運動に若干の物理的考察を加えることにする。図 -11 に示される Desna 川の例のように実際の弯曲河川 では外岸側で深掘れが生じ，内岸側で浅くなる現象が見 られる。これは単に河床のせん断力の分布のみでは説明 しえない。なぜなら，流入部付近の断面Ｉにおいては流 心が内岸側に存在し，せん断力が増大寸るにもかかわら ず内岸側ではほとんど掘れないで，横断面の形状はほぼ 長方形であるのに対して，下流の断面 IIでは流心が外岸 側に移りそこでは深く掘れているからである。断面 I 付 近では河道がほとんぞ直線的であり，しかも河向の変換 点であることから二次流はほとんど存在しないこと，ま た，弯曲部の河床付近では二次流の流向が内岸向きに偏 倚し砂粒子が内岸側へ運ばれるであろらことを考えると このような現象は二次流と密接な関連があることが推察 される。

ここでは弯曲水路を定常運動しながら移動している 1 個の砂粒子に注目して考察をすすめる。

砂粒子に働く力は回転による Magnus 効果, Coriolis 力を無視すると抗力, 揚力, 重力, 底による摩擦力, お よび遠心力の五つである。乱れは流れ方向の砂粒子の平 均的な移動速度に影響を与えないことが明らかになって いるのでここでは無視する ${ }^{11}$ 。ここれらの力のつり合いを それぞれ $R$ 方向， $\Theta$ 方向について考えると，
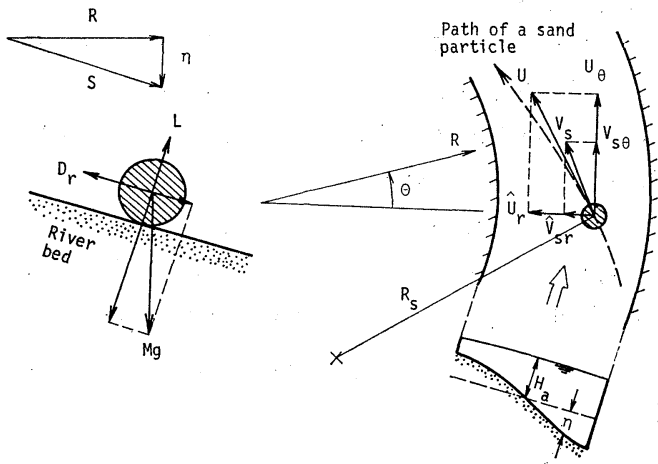

$$
\begin{aligned}
& \Theta: D_{\theta}+(M-m) g i_{\theta}-\mu\left\{(M-m) g \frac{d R}{d S}-L\right\} \\
& \text { - } \frac{V_{s \theta}}{V_{s}}=0
\end{aligned}
$$

$$
\begin{gathered}
R: D_{r}-(M-m) g \frac{d \eta}{d S}-\mu\left\{(M-m) g \frac{d R}{d S}-L\right\} \\
\cdot \frac{\hat{V}_{s r}}{V_{s}}-M \frac{V_{s}{ }^{2}}{R_{s}}=0 \cdots \cdots \cdots \cdots \cdots \cdots \cdots(2)
\end{gathered}
$$

となる。ここに，

$\Theta, R$ : 円筒座標系における接線および半径方向を示

$$
\text { す (図一1) }
$$

$\eta$ : 河床の平均水深 $H_{a}$ からの掘れ $\left(H=H_{a}+\eta\right)$

$D_{\theta}, D_{r}$ : 砂粒子に対して $\theta, R$ 方向に働いている抗力

$L:$ 砂粒子に働く揚力

$M:$ 砂粒子の質量 $\left(=\pi / 6 \cdot \rho_{s} d^{3}\right)$

$m:$ 砂粒子と同体積の水の質量 $\left(=\pi / 6 \bullet \rho d^{3}\right)$

$g:$ 重力の加速度

$i_{\theta}: \Theta$ 方向一の河床勾配

$V_{s}:$ 砂粒子の移動速度

$V_{s \theta}, \hat{V}_{s r}: V_{s} \rho \theta$ 方向, $R$ 方向の成分

$R_{s}:$ 砂粒子の軌道の曲率半径

$$
\mu: \text { 動摩擦係数 }
$$

である。次にこれらの力の評価を行う。砂粒子の形状を 球とすれば,

(1) 抗 力

$$
D=\frac{\rho}{2} C_{D} \frac{\pi}{4} d^{2}\left(U-V_{s}\right)^{2}
$$

ここに,

$C_{D}:$ 抗力係数

$U:$ 砂粒子の中心高さにおける流れの平均速度

$d:$ 砂粒子の直径

ところで，流れの方向と砂粒子の移動方向が一致しない 場合に式 (3) で抗力 $D$ を表現しうるかという疑問が生 ずる。河床の横断形状が安定勾配に達し，砂粒子が河岸 と同心円状の軌跡を描いて動いているときに $U$ の方向 と $V_{s}$ の方向が最も異なるが，このような場合でも式 (3) のように表現することによって生ずる誤差は $\left(U_{r} / U_{\theta}\right)^{2}$ の order であり，一般に $U_{r}$ は $U_{\theta}$ に比べて十分小さ いのでこのような表現によっても抗力 $D$ を十分精度よ く表現しうるものと考えられる。よって $D_{\theta}, D_{r}$ は

$$
\begin{aligned}
& D_{\theta}=D \cdot \frac{U_{\theta}-V_{s \theta}}{U-V_{s}} \\
& D_{r}=D \cdot \frac{\hat{U}_{r}-\hat{V}_{s r}}{U-V_{s}}
\end{aligned}
$$

となる。ただし， $\hat{U}_{r}, \hat{V}_{s r}$ はそれぞれ砂粒子の軌道が内 向きであるので，内岸向きを正としてある。 


\section{（2）揚 力}

$$
L=\frac{\rho}{2} C_{L} \frac{\pi}{4} d^{2}\left(U-V_{s}\right)^{2}
$$

ここに,

$C_{L}:$ 揚力係数

である。

ここで河床が内岸側で高くなり，底層付近の流れが砂 粒子に及ぼす内向きの力と外岸側へ働く力の成分が等し くなり, 力学的なつり合いの状態に達し, 砂粒子が河岸 と同心円状の軌道を動くょうになると砂粒子の $R$ 方向 への速度成分 $\hat{V}_{s r}$ および $D_{r}$ はそれぞれ

$$
\begin{aligned}
\hat{V}_{s r} & =0 \\
D_{r} & =D \cdot \frac{\hat{U}_{r}-\hat{V}_{s r}}{U-V_{s}} \\
& =D \cdot \frac{\hat{U}_{r}}{U-\bar{V}_{s}}
\end{aligned}
$$

となる。 $\hat{V}_{s r}=0$ であるので

$$
\begin{aligned}
& \frac{V_{s \theta}}{V_{s}}=1 \\
& D_{\theta}=D \cdot \frac{U_{\theta}-V_{s \theta}}{U-V_{s}} \fallingdotseq D
\end{aligned}
$$

と表わすことができる。これらの表現を式 (1)，(2) に 代入する。式 (1) からは次の関係を得ることができる。

$$
\begin{aligned}
& \frac{\rho}{8} \pi d^{2}\left(C_{D}+\mu C_{L}\right)\left(U-V_{s}\right)^{2} \\
& \quad=\left(\mu \frac{d R}{d S}-i_{\theta}\right) \frac{\pi}{6} d^{3}\left(\rho_{s}-\rho\right) g
\end{aligned}
$$

同様に式 (2) からは，

$$
\begin{aligned}
& \frac{d \eta}{d S}=\frac{3}{4} \frac{C_{D}}{g d\left(\frac{\rho_{s}}{\rho}-1\right)}\left(U-V_{s}\right) \cdot \hat{U}_{r} \\
& -\frac{V_{s}{ }^{2}}{g R_{s}} \frac{1}{\left(1-\frac{\rho}{\rho_{s}}\right)}
\end{aligned}
$$

を得る。式 (6)，(7) の両式から $U-V_{s}$ を消去するた めに式 (6) から $U-V_{s}$ を求める。このとき常に $U$ $V_{s} \geq 0$ であることを考えて,

$$
U-V_{s}=\left\{\frac{4}{3} \frac{g d\left(\frac{\rho_{s}}{\rho}-1\right)}{C_{D}+\mu C_{L}}\left(\mu \frac{d R}{d S}-i_{\theta}\right)\right\}^{1 / 2}
$$

を得る。この式を式 (7) に代入すると末知の量である $U-V_{s}$ を消去することができ, 横断方向の動的な平衡 河床勾配を表わす式,

$$
\begin{aligned}
\frac{d \eta}{d S} & =\left\{\frac{3}{4} \frac{C_{D}}{1+\mu \frac{C_{L}}{C_{D}}}\left(\mu \frac{d R}{d S}-i_{\theta}\right)\right\}^{1 / 2} \\
& \cdot \frac{\hat{U}_{r}}{\left\{\left(\frac{\rho_{s}}{\rho}-1\right) g d\right\}^{1 / 2}}-\frac{V_{s}^{2}}{g R_{s}\left(1-\frac{\rho}{\rho_{s}}\right)} \cdots
\end{aligned}
$$

を得ることができる。ここで式 (8)・を簡単にするため
に各項の order の見積りを行ってみる。 $R$ 方向への河 床公配は，一般には $1 / 10$ 程度であるから，

$$
d S=d R\left\{1+\left(\frac{d \eta}{d R}\right)^{2}\right\}^{1 / 2} \simeq d R(1+0.005)
$$

となり十分な精度で，

$$
\frac{d R}{d S} \fallingdotseq 1, \frac{d \eta}{d S} \fallingdotseq \frac{d \eta}{d R}
$$

とおくことができる。次に $\mu \cdot d R / d S \fallingdotseq \mu$ と $i_{\theta}$ の order の比較を行ってみると, 後に示すように実験によれば $\mu$ は 0.3 0.5 程度であり, 一般に流れ方向の河床勾配が 1/500 を超えることはまずないことを考えると，

$$
\mu \frac{d R}{d S} \gg i_{\theta}
$$

である。また, 式 (8) の右辺の二項の order を実験室 の程度で見積ってみると, 通常の状態では砂粒子自身の 運動による遠心力を表わす右辺第二項は, 右辺第一項の 高々 $1 \%$ 程度であり，一般の河川では曲率半径 $R_{s}$ が 非常に大きく遠心力の及ぼす影響はますます小さくなる ことを考えると右辺第二項は十分精度よく無視すること ができる。これらの考察によって結局河川弯曲部におけ る動的な安定横断河床形状を表わす式（8）は次のよう に簡略化することができる。

$$
\frac{d \eta}{d R}=\left(\frac{3}{4} \mu \frac{C_{D}}{1+\mu \frac{C_{L}}{C_{D}}}\right)^{1 / 2} \frac{\hat{U}_{r}}{\left\{\left(\frac{\rho_{s}}{\rho}-1\right) g d\right\}^{1 / 2}}
$$

上式によって河床形状が決定されるが，横断方向の勾 配に二次流の成分 $\hat{U}_{r}$ が直接的に影響を及ぼし, $\hat{U}_{r}$ が 大きいほど勾配が大きくなる。すなわち, 外岸側で掘 れ, 内岸側で堆積が顕著になることがわかる。また, 河 床材料の比重が大きいほど 勾配は小さく, 粒子の径 $d$ が小さいほど勾配が大きくなることもわかる。

式 (9) 中の各係数,

$$
\mu, C_{D}, \frac{C_{L}}{C_{D}}
$$

の值を知る必要があるが，それらについては，筆者 ${ }^{11}$ は $\mu$ を測定し, さらに河床砂の場合の $C_{L}, C_{D}$ に関する Chepil の実験 ${ }^{10)}$ の整理を行っており，その結果を用い ることができる。図一2に $\mu$ の測定結果, 図一3に $C_{L} /$ $C_{D}$ の值を示しておいた。 $C_{L} / C_{D}$ に関しては $R_{e *}$ の広 い範囲にわたって一定であることがわかる。これから河 床上を動く砂粒子に対しては,

$$
\mu=0.43, \frac{C_{L}}{C_{D}} \simeq 0.85
$$

を用いることができる。一方， $C_{D}$ については乱流の場 合の球の抵抗係数,

$$
C_{D} \simeq 0.4
$$

を用いることにする。 


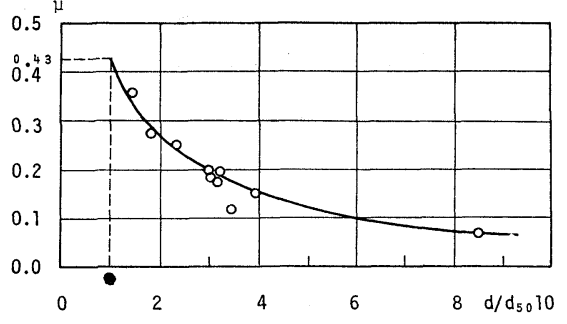

図-2 動摩擦係数 $\mu$ の測定値

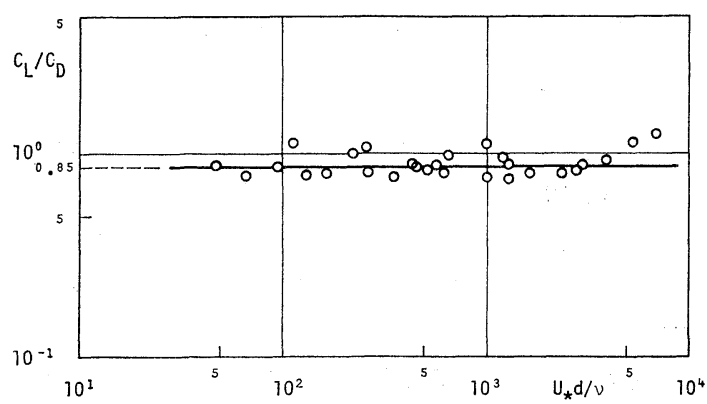

図-3 $C_{L} / C_{D}$ と $U_{*} d / \nu$ の関係

これらから河床の横断形状は二次流の大きさ $\hat{U}_{r}$, 砂 粒子と水の密度の比 $\rho_{s} / \rho$ (一般には 2.65 程度である), 河床を構成する砂粒子の平均粒径 $d$ が与えられれば式 （9）によって理論的に求めることが可能である。

$\hat{U}_{r}$ については筆者ら ${ }^{12)}$ によって得られた乱流の場合 の理論は長方形断面の場合であるので，任意の断面形に ついて二次流の成分 $\hat{U}_{r}$ を理論的に求める必要がある。 したがって，その理論式が求まると式（9）と連立させ ることによって, 流量等の水理量, 川幅, 曲率半径等の 幾何学形状，および粒径等の河床構成材料に関する情報 が与えられると安定な横断河床形状をあらかじめ予測す ることができる可能性がある。このような理由によっ て, 次章では任意の断面形に扔ける二次流の速度分布に ついて考察をすすめることとする。

\section{3. 横断方向に水深が変化する場合の二次流の 速度分布}

長方形断面の場合には非線型項は側壁近傍以外ではほ とんど無視でき，しかも側壁の影響は側壁近傍に限られ ていることが，理論的にも実験的にも確かめられている が12)，任意の断面形についてこのような結論が得られる かどらかは断言できない。けれども断面形が長方形から 極端に異ならない場合にはこのような仮定を用いても差 しつかえないであろらと思われる。また，水深に比べて 水路幅が十分に大きい場合について考えると側壁の影響 はほとんど皆無である。したがって横断方向に水深が変
化する場合には運動方程式中の非線型項, および側壁の 影響を無視して考察をすすめることにする。このような 場合には二次流の速度分布は, 側壁を考慮した場合の 式12),

$$
\frac{\partial^{4} \psi}{\partial R^{4}}+2 \frac{\partial^{4} \psi}{\partial R^{2} \partial Z^{2}}+\frac{\partial^{4} \psi}{\partial Z^{4}}=-\frac{2}{\varepsilon} U_{\theta} \frac{\partial U_{\theta}}{\partial Z}
$$

の中で $R$ によって偏微分された項を除いた式,

$$
\frac{\partial^{4} \psi}{\partial Z^{4}}=-\frac{2}{\varepsilon} U_{\theta} \frac{\partial U_{\theta}}{\partial Z}
$$

によって決定される。ここに廿は二次流に関する流関 数である。

$U_{\theta}$ の分布として粗滑両面に対して用いることができ るように速度欠損則,

$$
\frac{U_{\max }-U_{\theta}}{U_{*}}=-\frac{1}{\kappa} \log \frac{Z}{H}
$$

を用いることにする。上式を平均流速 $U_{a}$ で表わしてお くと,

$$
\frac{U_{\theta}}{U_{*}}=f\left(\frac{R}{R_{0}}\right)\left\{\frac{U_{a}}{U_{*}}+\frac{1}{\kappa}\left(\log \frac{Z}{H}+1\right)\right\} \cdots
$$

である。ここに $f=R$ 方向への $U_{\theta}$ の分布形であって, 全断面で平均寸れば 1 である。一般には $f$ は強制渦型 であるが, 側壁近傍では減少する。移動床の弯曲水路に おいて断面形が長方形でない場合にも主流の $R$ 方向の 速度分布が強制渦型となることは，須賀 められておりここでもその分布形を用いることにする。 ここで後の計算の簡略化のために変数変換, $\xi=Z / H$ を 行う。また, 弯曲水路に扔ける 渦動粘性係数について

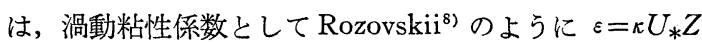
・ $(1-Z / H)$ を用いると, 底部で二次流の速度が無限大 となり, また, 変化率 $\partial U_{r} / \partial z$ が大きくなり, 底部付近 で正確にその大きさが決まらない。これを防ぐには境界 層の概念を導入するか，あるいは Lane-Kalinske が浮 遊砂の濃度分布を求めるに際して底で濃度が無限大とな るのを防ぐために採用したように渦動粘性係数として深 さ方向の平均值 $U_{*} H / 15$ を用いるかが考えられる。河 床面が半径方向に水平でない場合には境界層の厚さを見 積ることが困難であることと，境界層を導入すると計算 が非常に複雑となることから，ここでは深さ方向に平均 した值,

$$
\varepsilon=\frac{U_{*} H}{15}
$$

を用いる。そうすると式 (12)，(13) はそれぞれ

$$
\begin{aligned}
& \frac{\partial^{4} \psi}{\partial \xi^{4}}=-\frac{30 H^{2}}{U_{*}} U_{\theta} \frac{\partial U_{\theta}}{\partial \xi} \\
& \frac{U_{\theta}}{U_{*}}=f\left(\frac{R}{R_{0}}\right)\left\{\frac{U_{a}}{U_{*}}+\frac{1}{\kappa}(\log \xi+1)\right\}
\end{aligned}
$$

となる。式 $\left(13^{\prime}\right)$ を式 $\left(12^{\prime}\right)$ に代入して $\xi$ に関して積 分を行い, その際に境界条件 


$$
\left.\begin{array}{l}
Z=0 \quad \text { (底) }: \psi=0, \frac{\partial^{2} \psi}{\partial \xi^{2}}=0 \\
Z=H \text { (水面) }: \psi=0, \frac{\partial^{2} \psi}{\partial \xi^{2}}=0
\end{array}\right\}
$$

に注意すれば，二次流の流関数 廿を求めることができ， これから

$$
U_{r}=\frac{1}{R} \frac{\partial \psi}{\partial Z}
$$

によって横断方向の二次流の速度分布を求めることがで きる。そうすると $U_{r}$ は次式によって与えられる。

$$
\frac{U_{r}}{U_{a}}=f^{2} \cdot \frac{H}{R} \frac{1}{\kappa}\left\{F_{A}(\xi)-\frac{1}{\kappa} \frac{U_{*}}{U_{a}} F_{B}(\xi)\right\}
$$

$$
\text { ここに, }
$$

$$
\begin{aligned}
& F_{A}(\xi)=-15\left(\xi^{2} \log \xi-\frac{1}{2} \xi^{2}+\frac{15}{54}\right) \cdots \cdots \cdots \\
& F_{B}(\xi)=\frac{15}{2}\left(\xi^{2} \log ^{2} \xi-\xi^{2} \log \xi+\frac{1}{2} \xi^{2}-\frac{19}{54}\right)
\end{aligned}
$$

である。 $F_{A}(\xi), F_{B}(\xi)$ については, 図-4 にその関数 形が与えられている。

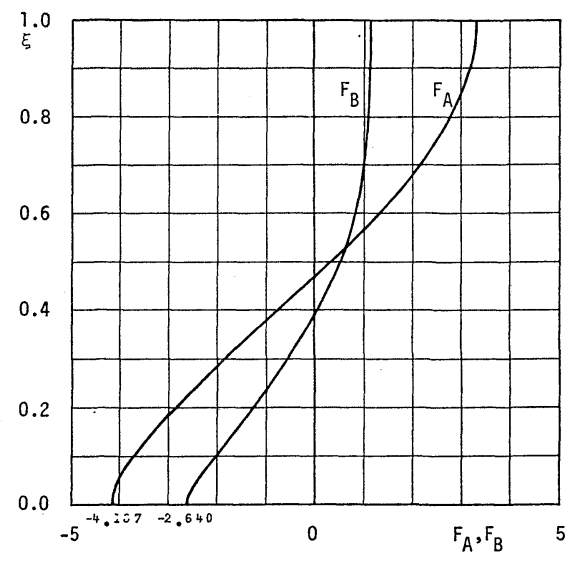

図-4 $\boldsymbol{F}_{A}, \boldsymbol{F}_{B}$ の関数形

一般の河川では $\kappa=0.4$ であるので

$$
F_{A}(\xi)-\frac{1}{\kappa} \frac{U_{*}}{U_{a}} F_{B}(\xi)
$$

の值は結局 $U_{*} / U_{a}$ によって決まることになる。したが っ

$$
\begin{aligned}
\frac{U_{r}}{U_{a}} & =f^{2} \frac{H}{R} \frac{1}{\kappa} F(\xi) \\
F(\xi) & =F_{A}(\xi)-\frac{1}{\kappa} \frac{U_{*}}{U_{a}} F_{B}(\xi)
\end{aligned}
$$

とおき, $U_{*} / U_{a}$ の各值について計算された $F(\xi)$ の分 布形を図一5 に示してある。 $U_{*} / U_{a}$ は一般に $1 / 6 \sim 1 / 20$ の間に存在するのでその範囲で計算されている。

ここで注意すべきは二次流の成分

$$
U_{r}=f^{2} Q \cdot \frac{1}{R} \frac{1}{\kappa}\left\{F_{A}(\xi)-\frac{1}{\kappa} \frac{U_{*}}{U_{a}} F_{B}(\xi)\right\}
$$

$$
Q=U_{a} H
$$

が $U_{a} / U_{*}$ の関数になっていることである。主流の対数 分布則を水深方向に積分して求めた式,

$$
\frac{U_{a}}{U_{*}}=6.0+5.75 \log _{10} \frac{H}{k_{s}}
$$

から $U_{a} / U_{*}$ は相当粗度 $k_{s}$ の関数であることがわかる が，両式を結びつけると流量 $Q$ が同一である場合には 粗面になるほど二次流の大きさは減少することがわか る。けれども, 図一5 に示されているようにその差異は あまり大きくなく,一般の河川の流れでは $U_{*} / U_{a}=1 / 10$ 〜1/20 程度であるので, ほとんど変わらないと考えて よいであろう。

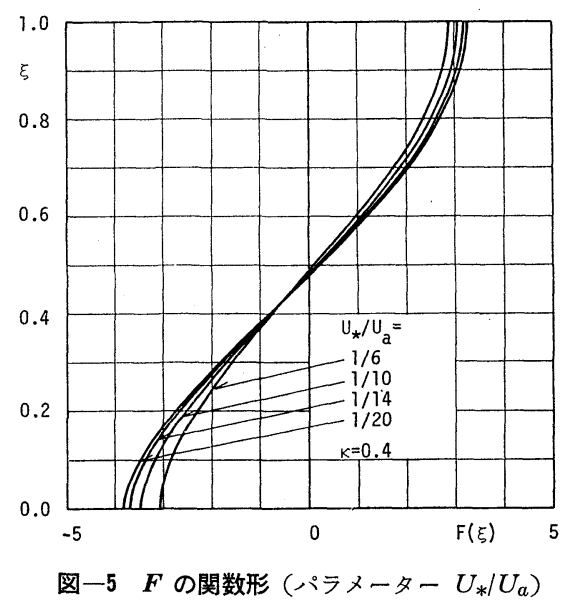

これから二次流の $R$ 方向の成分 $U_{r}$ をきわめて容易 に求めることができる。 $f$ については主流の横断方向の 分布形によって決まり，

$$
\text { 強制渦型 } \quad: f=\frac{R}{R_{0}}
$$

横断方向に一定 : $f=1$

$$
\text { 自由渦型 }: f=\frac{R_{0}}{R}
$$

である。ここに $R_{0}$ は平均流速 $U_{a}$ が生ずる地点の曲 率半径である。

Rozovskii によって得られた粗面の場合の式 ${ }^{8)}$,

$$
U_{r}=U_{a} \frac{1}{\kappa^{2}} \frac{H}{R}\left\{F_{1}\left(\frac{Z}{H}\right)-\frac{\sqrt{g}}{\kappa c} F_{4}\left(\frac{Z}{H}\right)\right\}
$$

は $F_{4}$ の性質上 $Z=0$ 近傍で $F_{4} \rightarrow-\infty$ に漸近し正確に その值が定まらないの比べて, ここで求められた式 (19) は底部付近で安定しており, 底部付近の二次流の速度が 重要となる砂粒子の移動の問題を取扱う場合にはきわめ て便利であるといえる。

\section{4. 横断方向の平衡河床形状について}

河床形状を決定する方程式（9）と二次流を 決定する 方程式 (19) から安定な横断河床形状を求めることがで 
きる。計算の都合上式 (9) 中の $\hat{U}_{r}$ は内岸向きを正, 式 (19) 中の $U_{r}$ は外向き正としてあったので,

$$
\hat{U}_{r}=-U_{r}
$$

である。砂の移動を決定するのは底面における流れであ るので，底面における二次流の大きさを $U_{r}=U_{r}(0)$ と すると方程式（9），(19）はそれぞれ，

$$
\begin{aligned}
& \frac{d \eta}{d R}=-\left(\frac{3}{4} \frac{\mu C_{D}}{1+\mu \frac{C_{L}}{C_{D}}}\right)^{1 / 2} \frac{U_{r}(0)}{\left\{\left(\frac{\rho_{s}}{\rho}-1\right) g d\right\}^{1 / 2}} \\
& \ldots \ldots \ldots \ldots \ldots \ldots \ldots \ldots \ldots \ldots\left(9^{\prime}\right) \\
& U_{r}(0)=U_{a} f^{2} \frac{H}{R} \cdot \frac{1}{\kappa} F(0) \quad \ldots \ldots \ldots \ldots \ldots \ldots\left(19^{\prime}\right.
\end{aligned}
$$

となる。ここで $H=H_{a}+\eta$ であることを考え, 式 $\left(19^{\prime}\right)$ を式 $\left(9^{\prime}\right)$ に代入すると, 河床形状を決定する方程式,

$$
\begin{aligned}
\frac{d H}{d R}= & -\left(\frac{3}{4} \frac{\mu C_{D}}{1+\mu \frac{C_{L}}{C_{D}}}\right)^{1 / 2} \frac{U_{a}}{\left\{\left(\frac{\rho_{s}}{\rho}-1\right) g d\right\}^{1 / 2}} \\
& \cdot \frac{1}{\kappa} F(0) f^{2} \frac{H}{R} \quad \cdots \cdots \cdots \cdots \cdots \cdots \cdots \cdots(21)
\end{aligned}
$$

を得る。

式 (21) を積分し, その際に積分定数を $R=R_{a}$ で平 均水深 $H_{a}$ が生ずるといら条件,

$$
R=R_{a}: H=H_{a}
$$

によって定めると解は $f$ の分布形 $(20 \mathrm{a}, \mathrm{b}, \mathrm{c})$ に応じ て決定することができ, 横断河床形状は次のように定め られる。

$$
\begin{aligned}
f= & \frac{R}{R_{0}} \text { (強制渦型) : } \\
& \frac{H}{H_{a}}=\exp \left\{\frac{1}{2} A \cdot \frac{R_{a}{ }^{2}}{R_{0}{ }^{2}}\left(\frac{R^{2}}{R_{a}^{2}}-1\right)\right\}
\end{aligned}
$$

$f=1$ (横断方向に一定) :

$$
\frac{H}{H_{a}}=\left(\frac{R}{R_{a}}\right)^{A}
$$

$f=\frac{R_{0}}{R}$ (自由渦型) :

$$
\frac{H}{H_{a}}=\exp \left\{\frac{1}{2} A \cdot \frac{R_{0}^{2}}{R_{a}^{2}}\left(1-\frac{R_{a}^{2}}{R^{2}}\right)\right\}
$$

ここに,

$$
\begin{aligned}
A= & -\left(\frac{3}{4} \frac{\mu C_{D}}{\left.1+\mu \frac{C_{L}}{C_{D}}\right)^{1 / 2}} \frac{\lambda U_{a}}{\left\{\left(\frac{\rho_{s}}{\rho}-1\right) g d\right\}^{1 / 2}}\right. \\
& \cdot \frac{1}{\kappa} F(0)
\end{aligned}
$$

である。

Aについては変形でき,

$$
\begin{aligned}
A= & -\left(\frac{3}{4} \frac{\mu C_{D}}{1+\mu \frac{C_{L}}{C_{D}}}\right)^{1 / 2} \frac{\lambda U_{*}}{\left\{\left(\frac{\rho_{s}}{\rho}-1\right) g d\right\}^{1 / 2}} \\
& \cdot \frac{1}{\kappa} \frac{U_{a}}{U_{*}}\left\{F_{A}(0)-\frac{1}{\kappa} \frac{U_{*}}{U_{a}} F_{B}(0)\right\}
\end{aligned}
$$

となる。これから $A$ は, $U_{*} /\left\{\left(\rho_{s} / \rho-1\right) g d\right\}^{1 / 2}$
と $U_{*} / U_{a}$ をパラメーターとして変化することがわか

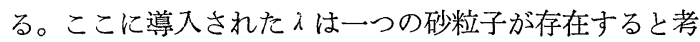
えた場合に比べて, 同じく表面に露出している他の粒子 によって遮蔽される効果の度合いであって一般に遮蔽係

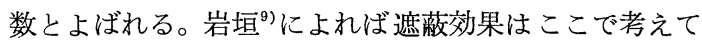
いるように砂粒子が全面的に動いているときには掃流力 $\left.U_{*}{ }^{2} /\left\{\rho_{s} / \rho-1\right) g d\right\}$ を 0.35 倍にする働きがあるとして

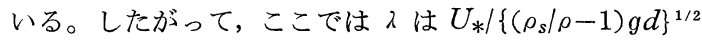
に対して定義されているので,

$$
\lambda=\sqrt{0.35}=0.592
$$

とする。その他の值は先に考察したように決められる。 すなわち，

$$
\begin{aligned}
\mu & =0.43 \\
C_{D} & =0.4 \\
\frac{C_{L}}{C_{D}} & =0.85 \\
\kappa & =0.4 \\
F_{A}(0) & =-4.167 \\
F_{B}(0) & =-2.640
\end{aligned}
$$

である。これから $A$ の值は, $U_{*} /\left\{\left(\rho_{s} / \rho-1\right) g d\right\}^{1 / 2}$ と $U_{*} / U_{a}$ によって決定することができる。図一6に $A$ と それらのパラメーターの間の関係が図示されている。乱 流域においては限界掃流力は $U_{* c}{ }^{2} /\left(\rho_{s} / \rho-1\right) g d \fallingdotseq 0.05$ であり，ここでは動的安定河床勾配を取扱っているので 砂粒子が動く領域, $U_{*} /\left\{\left(\rho_{s} / \rho-1\right) g d\right\}^{1 / 2}>0.22$ につW て計算を行ってある。ここで注意すべきは $F_{0}(0)<0$ で あるので $A$ の值は常に正となり, $f$ の分布形に関係な. く外岸側で深掘れが発生することである。けれども実際 には完全発達域で $f$ が自由渦型になることはありえず， 自由渦型については理論的な意味しか持っていない。 $A$ の值は $U_{*} / U_{a}$ と $U_{*} /\left\{\left(\rho_{s} / \rho-1\right) g d\right\}^{1 / 2}$ によって決定さ れるので両者と $A$ 関係を図一6に示しておいた。

一般の弯曲部流れでは $f=R / R_{0}$ の強制渦型であるの で, その場合について $A$ 值の変化に伴う河床形状の相 違を式 (22 a ) によって計算し, 図一7 に図示しておい た。ただし, この場合水路幅が決定していないので $R_{a} l$ $R_{0}$ の值を定めることができず，近似的に $R_{a} / R_{0}=1$ と して計算を行ってある。けれども一般には $R_{a}$ と $R_{0}$ の 值はほとんど違わず常に 1 とおいてよい。以上の計算の 結果によって平均流速 $U_{a}$, 摩擦速度 $U_{*}$ (または平均水 深 $H_{a}$ と水路勾配 $\left.i_{\theta}\right)$ および河床の砂粒子の粒径 $d$ が 与えられれば図一6，7 を利用することによって安定な 河床形状をきわめて簡単に求めることができる。

$f$ すなわち主流の横断方向の分布が河床形状に及ぼす 影響を調べるために強制渦型, 一定, 自由渦型の 3 つの 場合に対して $A=5$ として計算を行い, 比較を行った。 

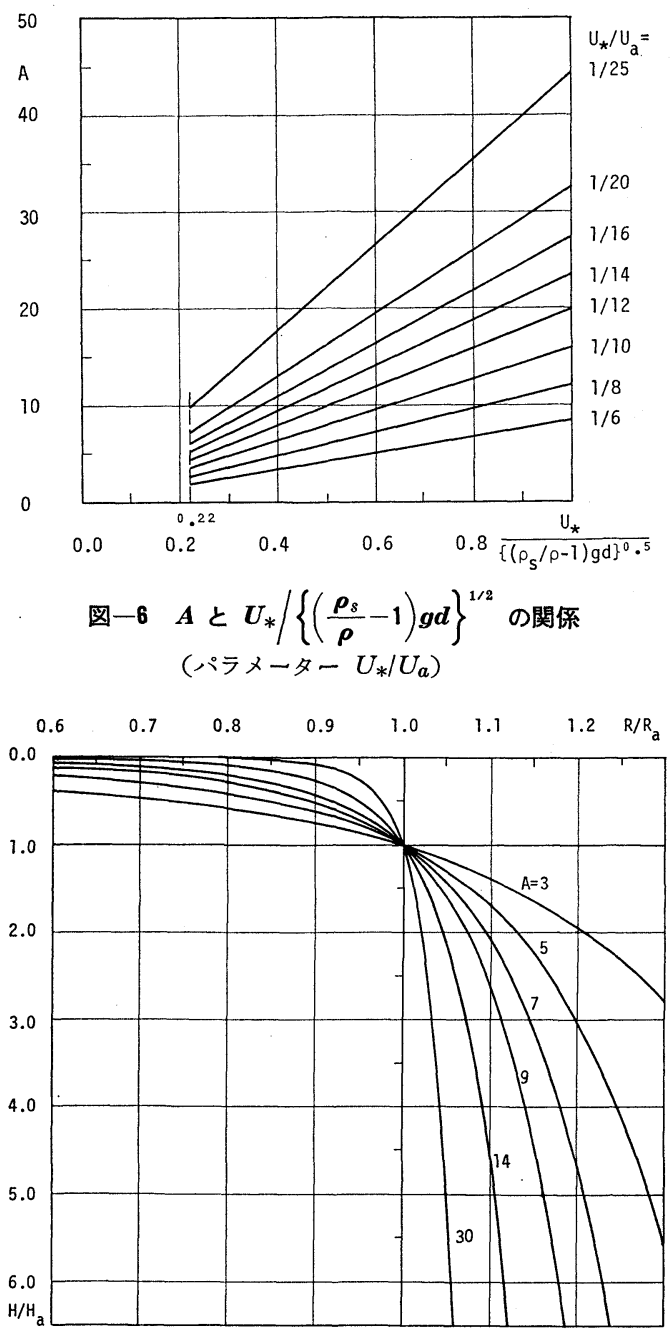

図-7 $\boldsymbol{H} / \boldsymbol{H}_{a}$ と $\boldsymbol{R} / \boldsymbol{R}_{a}$ の関係 (パラメーター $A$ )

これから当然予想されることであるが実際の流れで見ら れる強制渦型の場合が最も掘れることがわかる。

\section{5. 理論値と実験値, 野外測定値の比較, 検討}

理論の検証を行らために実験值および野外測定值との 比較を行った。

実験值は，Yen（1970）によって得られたものを用い た。Yen は $90^{\circ}$ の弯曲部を持つ実験水路において河床

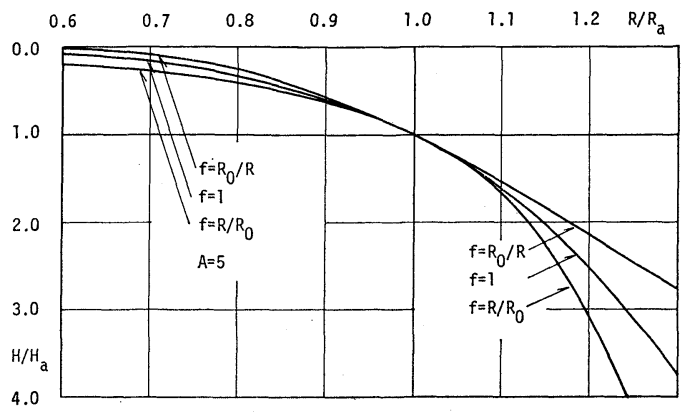

図一8 分布形 $f$ による河床形状の変化

形状の測定を行い，詳細な河床等高線図を得ている。彼 の実験によれば弯曲部に流入して約 $\pi / 6\left(30^{\circ}\right.$ 度) 程度で 河床形状は流れ方向に変化しなくなっており，この結果 は Rozovskii ${ }^{8)}$ によって得られた Desna 川の野外測定 值（図一11）とほとんど一致する。ここで得られた理論 結果と Yen の実験值を比較するに当っては弯曲部の流 入部から $3 / 8 \pi$ 下流における值を用いた。この地点では 流れおよび河床は完全に流れ方向に変化しなくなってお り，しかも下流側の影響を受けないからである。実験の 主な諸元は $\mathrm{cm} / \mathrm{sec}$ 単位に換算されて表一1 に示されて いる。

式 (22 a ) から計算される安定河床形状と Yen によ って得られた形状の比較が 図一10 に示されている。 Yen のデータにおいては水面勾配が明らかでないので

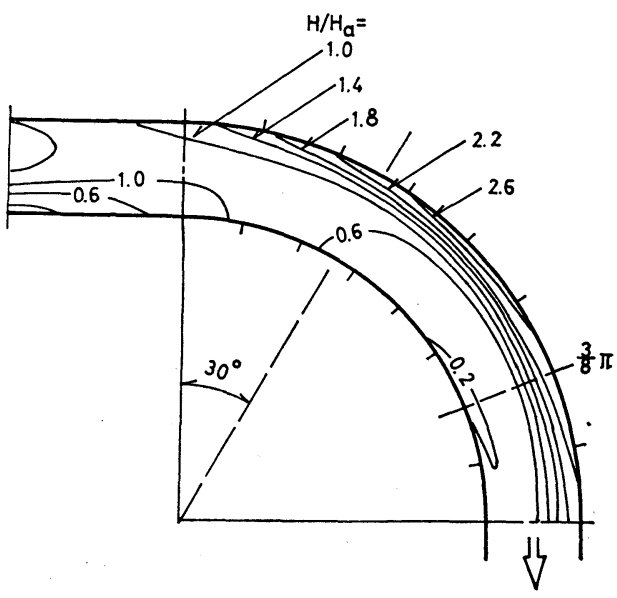

図一9＼cjkstart実験水路における河床等高線（Yen による）

表-1 Yen の実 験 值

Yen, C.L. (1970) Run $5 \frac{3}{8} \pi$ from the entrance

\begin{tabular}{c|c|c|c|c|c|c}
\hline $\begin{array}{c}\text { Width to depth } \\
\text { ratio } \\
B / H_{a}\end{array}$ & $\begin{array}{c}\text { Depth of flow } \\
H_{a}(\mathrm{~cm})\end{array}$ & $\begin{array}{c}\text { Central radius } \\
R_{c}(\mathrm{~cm})\end{array}$ & $\begin{array}{c}\text { Velocity of flow } \\
U_{a}(\mathrm{~cm} / \mathrm{s})\end{array}$ & $\begin{array}{c}\text { Mean diameter } \\
\text { of particle } \\
d(\mathrm{~mm})\end{array}$ & $\begin{array}{c}\text { Froude number } \\
F_{r}\end{array}$ & $\begin{array}{c}\text { Reynolds number } \\
R_{\boldsymbol{e}}\left(\times 10^{5}\right)\end{array}$ \\
\hline 30 & $7.78(0.255 \mathrm{f})$ & $853(28 \mathrm{f})$ & $61.2(2.009 \mathrm{f} / \mathrm{s})$ & 0.3 & 0.7 & 1.600 \\
\hline
\end{tabular}


計算に当っては $U_{*} / U_{a}$ の值は $1 / 10$ とした。けれども $A$ は,

$$
\begin{aligned}
A=- & \left(\frac{3}{4} \frac{\mu C_{D}}{1+\mu \frac{C_{L}}{C_{D}}}\right)^{1 / 2} \frac{\lambda U_{a}}{\left\{\left(\frac{\rho_{s}}{\rho}-1\right) g d\right\}^{1 / 2}} \\
& \cdot \frac{1}{\kappa} F(0) \\
F(0)= & F_{A}(0)-\frac{1}{\kappa} \frac{U_{*}}{U_{a}} F_{B}(0)
\end{aligned}
$$

であり， $F(0)$ は前に述べたように $U_{*} / U_{a}$ の值によ。 てほとんど変化しないので， $A$ の值ひいては河床形状 にはあまり影響を及ぼさないことがわかる。理論值と実 験值は外岸側近傍を除いて非常によく一致している。側 壁近傍では二次流の大きさはほとんど 0 となることから このような形状になることが説明される。式 (22 a) に おいて分布形 $f$ は側壁近傍では速度が減少するために 強制渦型から離れてくるがこの変化を計算式中に導入す

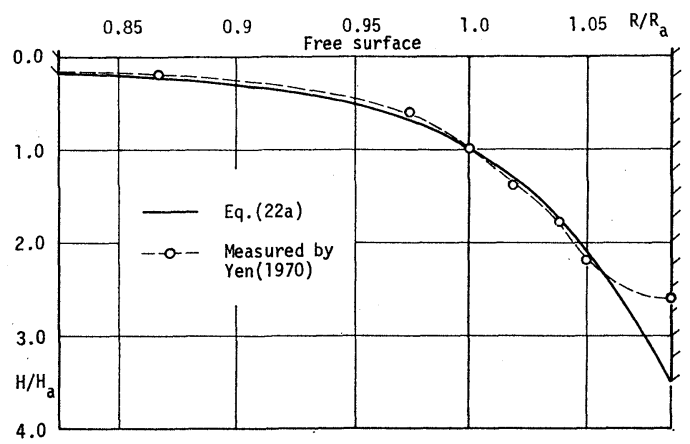

図一10河床横断形状に関する理論値と実験值の比較

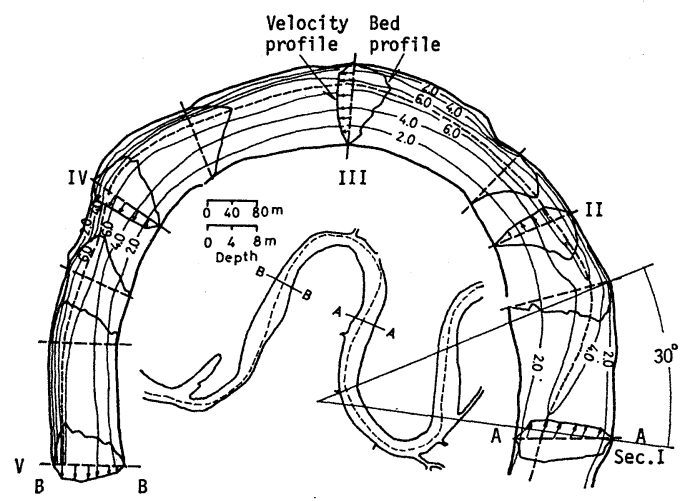

図一11 Desna 川における河床形状（Rozovskii による）
れば側壁近傍においても実験值とよく一致するものと思 われる。

次に野外測定值との比較を行う。測定值は Rozovskii によって Desna 川において得られたものを用いた。主 な諸元は 表一2 に示されている。

Rozovskii は二次流の速度分布, 河床形状についてと もに測定を行っているので二次流については式 (19) に よって得られる理論值との比較を 図一12 (b) に, 河床 形状については式 (22a) によって得られる值との比較 を図一12 (a) に示してある。図一12 (a) に示されてい るように実際の流れにおいても主流の横断方向の速度分 布は強制渦型であるので計算においても $f=R / R_{0}$ とし

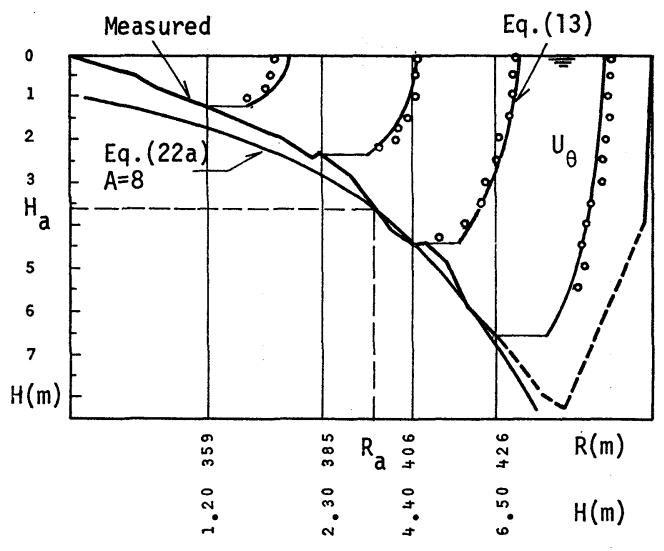

(a)
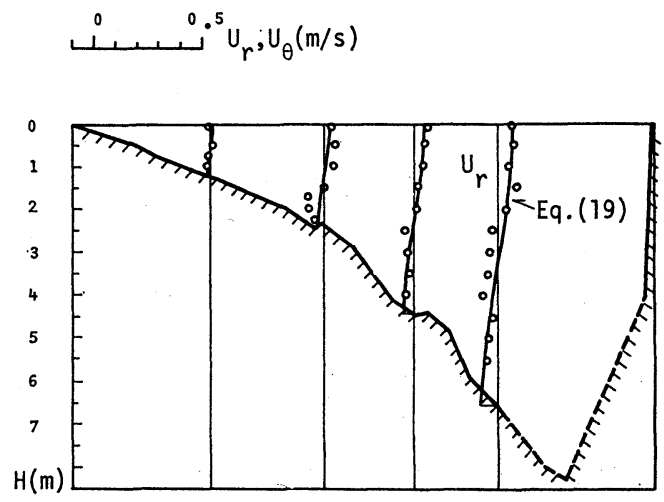

(b)

図-12 二次流と河床横断形状に関する 理論值と野外測定值の比較

表一2 Rozovskii の野外測定值

Rozovskii, I.L. (1957) Desna river Sec. II

\begin{tabular}{c|c|c|c|c|c|c}
\hline $\begin{array}{c}\text { Width to depth } \\
\text { ratio } \\
B / H_{a}\end{array}$ & $\begin{array}{c}\text { Depth of flow } \\
H_{a}(\mathrm{~m})\end{array}$ & $\begin{array}{c}\text { Central radius } \\
R_{c}(\mathrm{~m})\end{array}$ & $\begin{array}{c}\text { Velocity of flow } \\
U_{a}(\mathrm{~m} / \mathrm{s})\end{array}$ & $\begin{array}{c}\text { Longitudinal slope of } \\
\text { the water surface } \\
i_{\theta}\end{array}$ & $U_{a} / U_{*}$ & Chezy coefficient \\
\hline 37.2 & 3.6 & $\begin{array}{c}394 \\
R_{a}=396 \mathrm{~m}\end{array}$ & 0.4 & 0.0000274 & 12.8 & 42 to 45 \\
\hline
\end{tabular}


てある。二次流の速度分布については計算俥と実測值は よく一致しているといえる。河床形状についてはRozovskii のデータでは河床の砂粒子の粒度が明らかではない ので $A$ の值を明確に得ることができない。そこで河床 形状に最むよく一致する $A$ の值を求め, これから $d$ を 逆算することにした。 $A=8$ の場合が河床形状を最もよ く表わし，このとき， $A$ を表現する式から $d \fallingdotseq 0.43 \mathrm{~mm}$ を得ることができる。水面勾配 0.0000274 といら緩勾配 の河川の平均粒径としてはほぼ妥当な值であるといえる だろう。河床の形状は形態としては理論值と実測值はよ く合致しているといえる。

\section{6. 検 討}

害際の計算に当って注意を要する諸点を次に列記して おく。

最大洗掘深を求める場合には, 次のような点に注意し て計算を行えばよい。すなわち，Aの值がわかれば水路 幅 $B$ において洗掘される量と堆積する量が等しくなるよ 5 に式 (22 a ) によって $R_{a}$ を決め, これから外岸側に おける水深を計算すればよい。 $H / H_{a}$ の形状が指数型で あるので一般に $R_{a}$ は水路の中心における曲率半径 $R_{c}$ よりも大きくなる。強制渦型の場合について具体的に計 算を行ってみる。式 $(22 \mathrm{a})$ で $R_{a} / R_{0} \fallingdotseq 1$ であるので, 水梁は

$$
\frac{H}{H_{a}}=\exp \left\{\frac{1}{2} A\left(\frac{R^{2}}{R_{a}{ }^{2}}-1\right)\right\}
$$

となる。 $H=H_{a}+\eta$ を代入すると上式は

$$
\frac{\eta}{H_{a}}+1=\exp \left\{\frac{1}{2} A\left(\frac{R^{2}}{R_{a}^{2}}-1\right)\right\}
$$

となる。したがって, 洗掘量 $\eta$ は

$$
\frac{\eta}{H_{a}}=\exp \left\{\frac{1}{2} A\left(\frac{R^{2}}{R_{a}{ }^{2}}-1\right)\right\}-1
$$

である。この関数形は一般的に不定積分できないので, Simpson 公式を用いて $R / R_{a}$ に対して数值積分を行 う。そうすると図一13 に示されているように斜線の部 分の面積が相等しいような外岸側と内岸側の無次元曲率 半径 $\left(R / R_{a}\right)_{\text {outer }},\left(R / R_{a}\right)_{\text {inner }}$ をそれぞれ対応させて 求めてゆくことができ，それとともに $\left(R / R_{a}\right)_{\text {outer }}$ の 位置に扔海無次元水深 $H_{\max } / H_{a}$ を式 (23) 加計算 できる。ここで川幅 $B$ は

$$
\frac{B}{R_{a}}=\left(\frac{R}{R_{a}}\right)_{\text {outer }}-\left(\frac{R}{R_{a}}\right)_{\text {inner }}
$$

によって示される。ところで, ある移動床の弯曲水路が 与えられても平均水梁 $H_{a}$ が生ずる位置 $R_{a}$ がどこで 発生するかということは明白でないので，これを弯曲水 路の中心曲率半径 $R_{c}$ について書き直しておく。図一13 から

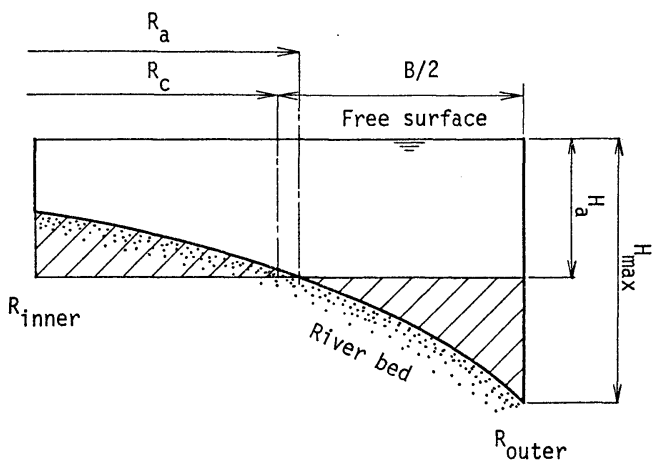

図一13 弯曲水路横断面の概念図

$$
\frac{R_{c}}{R_{a}}=\left(\frac{R}{R_{a}}\right)_{\text {inner }}+\left\{\left(\frac{R}{R_{a}}\right)_{\text {outer }}-\left(\frac{R}{R_{a}}\right)_{\text {inner }}\right\} / 2.0
$$

であるので，式 (25) とともに，

$$
\frac{B}{R_{c}}=\frac{\left(\frac{R}{R_{a}}\right)_{\text {outer }}-\left(\frac{R}{R_{a}}\right)_{\text {inner }}}{\left(\frac{R}{R_{a}}\right)_{\text {inner }}+\left\{\left(\frac{R}{R_{a}}\right)_{\text {outer }}-\left(\frac{R}{R_{a}}\right)_{\text {inner }}\right\} / 2.0}
$$

が求まる。よって最終的にある河川の幾何学形状 $B / R_{c}$ と掃流力に関する関数 $A$ の值がわかると, $\left(R / R_{a}\right)_{\text {outer }}$ に対応する最大洗掘深 と平均水深の比 $H_{\max } / H_{a}$ が求 められることになる。図一14 にはこのようにして求め られた $B / R_{c}$ と $A$ の值に対する $H_{\max } / H_{a}$ の計算值が プロットされている。この計算結果を検証するために Yen の実験結果 ${ }^{6)}$ との比較を行った。実験例が少なく, 明白なことはわからないが，計算值のほうがやや大きな 值を与えるようである。これは 図一10 において外岸側 で実際の河床よりも梁く掘れていることに対応している が，岸近くでは二次流の深さ方向の成分が卓越するし， また主流の速度も減少して強制渦型の分布からはずれて くるので，その効果をとり入れないと最大洗掘樑を精度 よく見積ることは困難であると思われる。

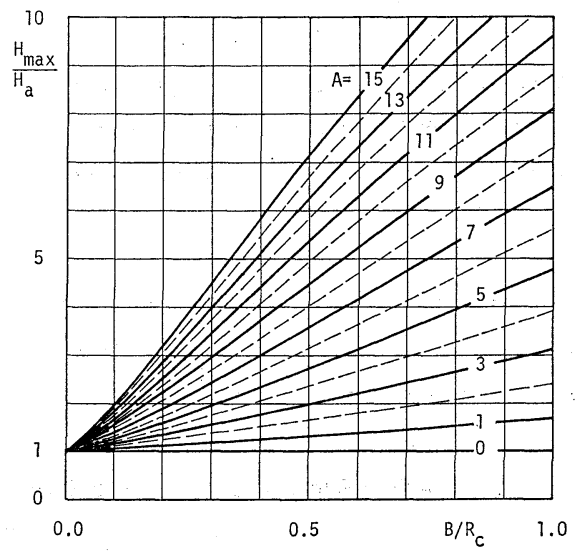

図一14 最大洗掘深と $B / R_{c}$ の関係 (パラメーター $A$ ) 


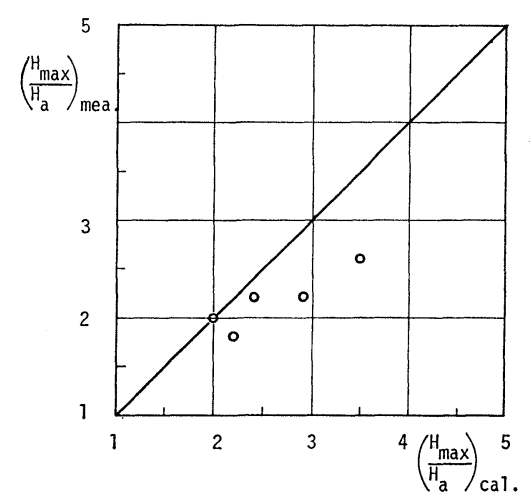

図一15 最大洗掘深の計算値と実験值 （Yen による）の比較

Yen の実験のように側壁が直立の固定壁になってい る場合にはこれらの効果を取り入れればかなり精度よく 最大洗掘媣を計算することができるであろらが，図一12 (a) の Desna 川のように実際河川では側壁そのものが 移動床となっているために計算された曲線が最後にどの ように外岸にすりついて行くのかは明白ではなない。な ぜなら, 外岸側の形状はここで論じられた力学的機構と はかなり異なった機構で決定されているであろらからで ある。ただ外岸側の勾配はかなり河床砂の水中安息角に 近いであろらから，実用的には安息角によって決められ る外岸の河床形と, ここで求められた大部分の領域にお いて成り立つ河床形状を決める曲線との交点を求める と, それがほぼ最大洗掘深を与えるものと思われる。け れども, 側壁近傍の河床形状を決定している力学的機構 を正しく把握することは最大洗掘深を正しく見積ること とも結びついて, 今後に残された課題であろう。

カルマンの定数については, ここでは， $\kappa=0.4$ とし てあるが，河川の流れに浮遊砂や Wash Load が含ま れる場合にはカルマンの定数 $\kappa$ の值は減少するので, そのような場合には志村または日野の式を用いて $\kappa$ を求 め式 (22 a ) によって河床形状を求めればよい。

本稿では式 $(22 \mathrm{a})$ による水深の見積りに際して遠心 カによる横断方向の水面変化を考慮していないが，それ が無視できない場合には水路勾配を表わす近似式

$$
i_{r} \simeq \frac{U_{a}^{2}}{g R}
$$

によって各地点における水面の上昇，下降を見積りそれ を式 (22a) によって得られる水深に付け加えればよい。

著者ら ${ }^{12)}$ は長方形断面では水路幅と水深の比 $B / H_{a}$ が 10 以下となると側壁等の影響等によって, 二次流を計 算するに当って主流の速度分布式として対数分布則を用 いることができなくなることを指摘したが，この場合む 同様であって二次流の速度分布を表わす式 (19) もB/
$H_{a}$ が十分大きい場合に対して成立することに注意され たい。

\section{7. 結 論}

以上の考察によって次の諸点が明らかになった。

(1) 二次流の大きさは $U_{a} / U_{*}$ の影響を受け, $U_{a}$ l U*が小さいほどすなわち底面が粗になるほど小さくな る。けれどもその差異は小さく, 図一5 に示されている ように一般の河川で滑らかな場合 $\left(U_{a} / U_{*}=20\right)$ でも最 も粗な場合 $\left(U_{a} / U_{*}=6\right)$ の約 1.25 倍になるにすぎな い。

（2）任意の断面における二次流の速度分布を表現す る式 (19) は野外の測定值とよく一致する。

（3）平衡河床形状を表わす式,

$$
\frac{H}{H_{a}}=\exp \left\{\frac{1}{2} A \frac{R_{a}{ }^{2}}{R_{0}{ }^{2}}\left(\frac{R^{2}}{R_{a}{ }^{2}}-1\right)\right\}
$$

を理論的に導き，それが横断方向のほぼ全域で実験值と よく一致することを示した。また，その形状は掃流力の 目安である $U_{*} /\left\{\left(\rho_{s} / \rho-1\right) g d\right\}^{1 / 2}$ と $U_{a} / U_{*}$ の関数とな ることが明らかになった。

（4）最大洗掘深は外岸において生じ, この式を用い るとその大きさを定量的に把握することができる。けれ ぞも, 岸近傍では横断方向の二次流が側壁によって小さ くなるために, 洗掘深は上式で計算される值よりも若干 緩和される。この点に関しては主流の横断方向の分布形 $f$ が側壁近傍で強制渦から変化し，その值が 0 に近づく ことを考慮すれば計算が可能である。

謝辞 : 本研究は Ripley の野外測定值に関して吉 川秀夫教授と議論を行ったのが発端であった。研究をす すめるに当って終始熱心な指導, 討議をいただいた同教 授に染く謝意を表わします。

\section{参 考 文 献}

1）野満隆治 原著, 瀬野錦蔵 補訂：新河川学, 地人書館, 1964.

2) Chow, V.T. : Open-Channel Hydraulics, McGRAWHILL, 1959.

3）須賀克三 : 開水路弯曲部河床の安定形状, 第 9 回水理講 演会講演集, 1965.

4）須賀克三: 開水路わえ曲部河床の安定形状 (その 2), 第 10 回水理講演会講演集, 1966.

5）須賀克三・馬場洋二：われ曲部の河床変動について，第 23 回建設省技術研究会報告, 建設省, 1969 .

6) Yen, C.L. : Bed Topography Effect on Flow in a Meander, Proc. ASCE, Hy. Div., HY 1., Jan., 1970.

7）村本嘉雄 - 坂本忠彦・吉村知司：弯曲水路の河床変動に 関する研究, 京都大学防災研究所年報, 11 B, 1968.

8) Rozovskii, I.L. : Flow of Water in Bends of Open Channel, Academy Sciences of the USSR, 1957.

9）岩垣雄一：限界掃流力に関する基礎的研究，土木学会論 文集 41 号, 1956. 
10) Chepil, W.S. : The Use of Evenly Spaced Hemispheres to Evaluate Aerodynamic Forces on a Soil Surface, Trans. A.G.U., Vol. 39, No. 3, June, 1958.

11) Ikeda, S. : Some Studies on the Mechanics of Bed Load Transport, Proc. of JSCE, No. 185, Jan., 1971.
12) Kikkawa, H., S. Ikeda, H. Ohkawa and Y. Kawamura : Secondary Flow in a Bend of Turbulent Stream., Proc. of JSCE, No. 219, Nov., 1973.

(1974.8.18 - 受付) 